Уипурене Айсте Барбора

д-р пед. наук, преподаватель Литовский университет спорта научный сотрудник

Университет Витаутаса Великого г. Каунас, Литовская Республика

DOI $10.21661 / r-508527$

\title{
COMMUNICATION PECULIARITIES OF ADOLESCENTS ATTENDING IN DANCE ACTIVITIES
}

Аннотация: танец и общение между подростками взаимосвязаны, поскольку общение - неотъемлемый элемент парного танца. Во время танцевальных занятий у подростков есть возможность значительно улучшить навыки общения, выявить и исправить свои недостатки, а также установить более близкие отношения со сверстниками. На настоящий момент вопрос общуения между танцуорами разных уровней и возрастов недостаточно освещчен в литературе. Научные исследования, описывающие влияние занятий танцуами на общение подростков, практически отсутствуют. Несмотря на это, влияние танцуа на общение между подростками является актуальной проблемой и представляет определенный интерес. Цель исследования -- определить уровень коммуникации между 14-16-летними подростками, посещуающими танц̧евальные занятия

Ключевые слова: подростки, коммуникативные навыки, занятия танцุами.

Abstract: dance is related to the peculiarities of communication between teenagers, because the essence of these dances is the performance of dance in a couple, During dance classes, adolescents have the opportunity to acquire excellent communication skills, to consciously discover and improve their weak points, to raise their communication level to a higher, more enjoyable level, There is lack of literature on 
communication between dancers of all ages and skill levels, There is a significant lack of scientific data on the impact of dance on adolescent communication.

Keywords: adolescents, communication skills, dancing activities.

\section{Introduction}

Communication is one of the most important human values. Without communication is impossible any professional training and development or any creative activity (Reinders, Bryden \& Fletcher, 2019). The need to communicate with each other is one of the most characteristic features of humanity. Artistic dance activity - a main tool for developing artistic abilities, aesthetic attitudes and tastes that are relevant to students' creativity and moral development (Uspuriene, 2019). Dance has become a necessity of communication and without it is difficult to be turned out. Dance is a great tool for strength, health, attractive relaxation, relaxation after school and work. It facilitates communication between people of different generations, nationalities, interests, and educational backgrounds (Pereira \& Marques-Pinto, 2018). Adolescence is a very responsible and difficult transition between childhood and adulthood, during this period the child grows up and matures and develops his or her social self-awareness. Changes in body and mind cause confusion in the soul of a growing child, sometimes pretending to be an early adult due to acceleration. Dance is very much related to the peculiarities of communication between teenagers, because the essence of these dances is the performance of dance in a couple. During dance classes, adolescents have the opportunity to acquire excellent communication skills, to consciously discover and improve their weak points, to raise their level of communication to a higher, more enjoyable level (Reinders, Bryden \& Fletcher, 2019).

There is a lack of literature on communication between dancers of all ages and skill levels. There is a significant lack of scientific data on the impact of dance on adolescent communication. The hypothesis is that the impact of dance on adolescent communication and the study of communication peculiarities is a topical issue worth exploring. 
Research aim - to determine the communication levels of 14-16 year old adolescents attending dance activities.

\section{Methods}

The research involved 62 adolescents ( 32 girls and 30 boys) attending dance classes. The levels of adolescent communication were determined using the V.F. Riachowski methodology (Рогов, 1999). The questionnaire allowed to choose between three answers - yes, sometimes and no - with 16 questions.

Assessment of answers: «yes»- 2 points, «sometimes»- 1 point, «no»0 points. The obtained results are summed up and the classifier determines to which category the subject belongs. The subjects were divided into the following categories according to their scores: «silent», «closed», «restrained», «communicating», «talking», «fountain», «diseased».

\section{Results}

The questionnaire that was provided to adolescents was intended to help determine their level of communication between teenagers attending dance classes. The author of this methodology has distinguished 7 levels of communication, from very speechless («silent») to too much talkative («diseased»).

After questioning adolescents attending dance classes, according to V.F. Riachowski methodology the lowest levels of «silent» and «closed» communication have not been identified.

Only 5 percent of girls and 8 percent of boys are considered to have a «restrained» level of communication. The most prevalent level of communication among dancing teenagers is «communicative», 47 percent of girls and 54 percent of boys corresponds to this level.,,Talkative» level of communication appropriates 37 percent surveyed girls and 26 percent of boys attending dance classes.

«Fountain»- the communication level, which according to the obtained indicators is assigned an equal number of girls and boys attending dance classes - 14 percent. There is no «talkative» or «diseased» communication level in this group. Most dancers adolescents depend of «communicative» level. 
The analysis revealed that dancing adolescents are characterized mostly by the «communicative» level. Adolescents at this level are curious, eager to listen to an interesting interlocutor, are patient enough to communicate, and defend their views without sudden outbursts of anger. Communicates with strangers without unpleasant fears. But dislikes noisy companies; extravagant attacks and verbosity annoying adolescents of this level.

\section{Список литературы}

1. Reinders N.J. Dance is something that anyone can do: Creating dance programs for all abilities / N.J. Reinders, P.J. Bryden, P.C. Fletcher // Research in Dance Education - 2019 - Vol. 20. - P. 257-274.

2. Pereira N.S. Development of a social and emotional learning program using educational dance: A participatory approach aimed at middle school students / N.S. Pereira, A. Marques-Pinto // Studies in Educational Evaluation - 2018 - Vol. 59. - P. 52-57.

3. Uspuriene A.B. The impact of non-formal artistic dance education on the communication and organizational abilities of adolescents // SOCIETY.INTEGRATION. EDUCATION Proceedings of the International Scientific Conference, May 24-25 th - 2019. - Vol. IV. - P. 549-554.

4. Рогов Е.И. Настольная книга практического психолога. - М.: Гуманит. 1999. $-384 \mathrm{c}$. 